\title{
CHANGE IN YIELD AND CHEMICAL COMPOSITION OF TALL FESCUE (Festuca arundinacea Schreb.) PLANTS UNDER SALT STRESS
}

\author{
Mahmut KAPLAN ${ }^{1}$, Mustafa BASER ${ }^{1}$, Hasan KALE ${ }^{1}$, Hasan Ali IRIK ${ }^{2 *}$, \\ Ismail ULGER ${ }^{3}$, Ali UNLUKARA ${ }^{2}$ \\ ${ }^{1}$ Erciyes University, Faculty of Agriculture, Department of Field Crops, Kayseri, TURKEY \\ ${ }^{2}$ Erciyes University, Faculty of Agriculture, Department of Biosystem Engineering, Kayseri, TURKEY \\ ${ }^{3}$ Erciyes University, Faculty of Agriculture, Department of Animal Science, Kayseri, TURKEY \\ *Corresponding author: haliirik42@gmail.com
}

Received: 03.08.2017

\begin{abstract}
The present study was conducted to investigate the effects of different irrigation water salinity levels $(0,3,5$ and $8 \mathrm{dS} / \mathrm{m}$ ) on hay yield, chemical composition, gas and methane production, metabolic energy (ME) and organic matter digestibility (OMD) of plants. Experiments were conducted in randomized blocks design with four replications for two years (2014-2015). Calcium chloride $\left(\mathrm{CaCl}_{2}\right)$, sodium chloride $(\mathrm{NaCl})$ and magnesium sulfate $\left.\mathrm{MgSO}_{4}\right)$ salts were used to prepare irrigation waters with different salinity levels. Drip irrigation was used. Fresh and dry hay yields, plant height, acid detergent fiber, neutral detergent fiber and crude oil contents decreased with increasing salt doses. Tall fescue Olympus cultivar exhibited a moderate tolerance to salinity. Fresh hay yield decreased by $8.2 \%$ at $1.85 \mathrm{dS} / \mathrm{m}$ threshold salinity level and dry hay yield decreased 8.2\% at $1.97 \mathrm{dS} / \mathrm{m}$ threshold salinity level. Crude protein content, gas and methane production, net energy lactation, metabolic energy and organic matter digestibility increased with increasing salt doses. Despite the decreases in hay yield, $8 \mathrm{dS} / \mathrm{m}$ did not result in any decreases in protein yields and resulted in low gas and methane production.
\end{abstract}

Key words: Gas production, hay yield, tall fescue.

\section{INTRODUCTION}

Salinity is a significant environmental factor influencing yield and quality in agricultural practices (Allakhverdiev et al., 2000). Worldwide, about $25 \%$ of total land resources (corresponding about 400 million ha) are under the threat of salinity (Tilaki et al., 2010) and the size of saline lands is increasing every day (Munns, 2005) together with mistakes made in irrigation and fertilization practices. In recent years for increasing salinity problems, either salt-resistant plants are bred or implementations are practiced to improve the salt resistance of the plants. Grasses are commonly used over these saline lands since they can well adapt to harsh soil conditions. These plants are also used in animal feeding (Martin et al., 2012). Festuca species grows over saline and alkaline soils better than the other grass species. It has also quite resistant to water ponding and poorly-drained soils (Efe, 2010).

Nutrient composition, metabolic energy and digestible nutrients are the greatest indicators of feed quality. Therefore, these parameters are commonly assessed in feed quality researches (Canbolat, 2012). Since being rapid, easy and cheap method, in vitro gas production technique is commonly used to determine nutritive values of the feeds (Kaplan et al., 2016). The in vitro gas production technique is also used in measuring methane $\left(\mathrm{CH}_{4}\right)$ production which is a significant factor in global warming (Lin et al., 2013).

Tall fescue (Festuca arundinacea Schreb) is moderately resistant to salinity (Moore, 1998) and previous salinity studies on Festuca sp. mostly investigated germination (Hanslin and Eggen, 2005), ion uptake (Alshammary, 2013), effects of salinity on physiological characteristics (Yan et al., 2008) and nutrient uptake (Banuelos et al., 1996) of tall fescue. The studies about the effects of salinity on hay yield and quality are quite limited.

The present study was conducted to investigate the effects of different salt stress levels on hay yield, chemical composition, metabolic energy (to be calculated through gas and methane production) and organic matter digestibility of tall fescue.

\section{MATERIALS AND METHODS}

\section{Field Experiments}

Field experiments were conducted in Kayseri province $\left(39^{\circ} 48^{\prime} \mathrm{N}\right.$; $\left.38^{\circ} 73^{\prime} \mathrm{E}\right)$ of Turkey during the years $2014-2015$ for two years. Tall fescue cv. Olympus was used as the 
plant material of the study. Plants were subjected to irrigation waters with 4 different salinity levels $\left(\mathrm{T}_{0}\right.$ : control, $\mathrm{T}_{1}: 3 \mathrm{dS} / \mathrm{m}, \mathrm{T}_{2}: 5 \mathrm{dS} / \mathrm{m}$ and $\left.\mathrm{T}_{3}: 8 \mathrm{dS} / \mathrm{m}\right)$. Plants were sown at the end of May 2013 and plants formed a grass cover. Seeds were sown at $30 \mathrm{~cm}$ row spacing as to have $1.5 \mathrm{~kg}$ seed per decare. Experiments were conducted in randomized blocks design with 4 replications. Plot sizes were $1.8 \times 5 \mathrm{~m}$ and each plot has 6 plant rows. A space (1 $\mathrm{m})$ was provided between the plots to prevent interactions among salt treatments. Fertilizations were performed based on soil analyses as to have $8 \mathrm{~kg} \mathrm{da}^{-1} \mathrm{~N}$ and $5 \mathrm{~kg} \mathrm{da}^{-1}$ $\mathrm{P}_{2} \mathrm{O}_{5}$. Following each harvest, $5 \mathrm{~kg} \mathrm{da}^{-1} \mathrm{~N}$ fertilization was also performed. Care practices were performed throughout the growing season. The first harvest was performed based on flowering period and the second harvests were performed based on the progress of plant growth. In harvests, the side rows and $50 \mathrm{~cm}$ strips from the plot ends were omitted as to consider side effect. The mid-section was harvested and weighed to get fresh hay yield. Then, $500 \mathrm{~g}$ sample was taken from fresh hay and samples were dried at $70{ }^{\circ} \mathrm{C}$ for 48 hours to get dry matter yield. Dry matter ratio was then multiplied by fresh hay yield to get dry hay yield.

\section{Salt doses and soil analysis}

In control treatment $\left(\mathrm{T}_{0}\right)$, water supplied from a deep well with an electrical conductivity value of $0.24 \mathrm{dS} / \mathrm{m}$ was used. To exert a salt stress on tall fescue plants, irrigation waters with different electrical conductivity (EC) levels $\left(\mathrm{EC}=3 \mathrm{dS} / \mathrm{m}\right.$ for $\mathrm{T}_{1} ; 5 \mathrm{dS} / \mathrm{m}$ for $\mathrm{T}_{2}$ and $8 \mathrm{dS} / \mathrm{m}$ for $T_{3}$ ) were applied. In this way, including control treatment, tall fescue plants were subjected to 4 different salinity levels. $\mathrm{NaCl}, \mathrm{CaCl}_{2}$ and $\mathrm{MgSO}_{4}$ salts were used to prepare saline irrigation waters. Amount of salt to be included in saline water was calculated for 3 different salinity levels as to have a sodium absorption rate (SAR) value of 5 and $\mathrm{Ca} / \mathrm{Mg}$ ratio of $1: 1$ (me/l). EC values of prepared saline waters were checked under laboratory conditions and they were made ready to be used in experiments following the relevant adjustments. For each saline irrigation water treatment, amount of salt $(\mathrm{g})$ added to 100 liter irrigation water is provided in Table 1.

Table 1. Amount of salt added to prepare irrigation waters with $\mathrm{EC}=3 \mathrm{dS} / \mathrm{m}, \mathrm{EC}=5 \mathrm{dS} / \mathrm{m}$ and EC= $8 \mathrm{dS} / \mathrm{m}(\mathrm{mg} / \mathrm{L})$

\begin{tabular}{cccccc}
\hline Treatment & $\mathbf{E C}(\mathbf{d S} / \mathbf{m})$ & $\mathbf{N a C l}(\mathbf{g})$ & $\mathbf{C a C l}_{\mathbf{2}} \mathbf{( g )}$ & $\mathbf{M g S O}_{\mathbf{4}}(\mathbf{g})$ & Total salt \\
\hline $\mathrm{T}_{1}$ & 3 & 0.414 & 0.846 & 1.421 & 2.681 \\
$\mathrm{~T}_{2}$ & 5 & 0.604 & 1.670 & 2.849 & 5.123 \\
$\mathrm{~T}_{3}$ & 8 & 0.842 & 3.120 & 5.237 & 9.199 \\
\hline
\end{tabular}

Soil moisture was monitored with a neutron meter (503DR Hydroprop). Amount of irrigation water to be applied in each irrigation was determined by using the following equation as to bring the deficit soil moisture in $0.5 \mathrm{~m}$ root zone into the field capacity (Ayers and Westcot, 1989; Unlukara et al., 2008):

$$
I=\frac{\left(\theta_{f c}-\theta_{a}\right) \cdot D \cdot A}{1-L F}
$$

I is the amount of irrigation water to be applied to plots (L), $\theta_{\mathrm{fc}}$ and $\theta_{\mathrm{a}}$ are respectively the field capacity and volumetric soil moisture content before each irrigation $\left(\mathrm{m}^{3} / \mathrm{m}^{3}\right), \mathrm{D}$ is the depth of plant root zone $(0.5 \mathrm{~m}), \mathrm{A}$ is plot size $\left(\mathrm{m}^{2}\right)$ and LF is leaching fraction. The leaching fraction was considered as $15 \%$ for each irrigation.

\section{Soil and climate parameters for research site}

Soil samples were taken from $0-40 \mathrm{~cm}$ soil profile throughout the experimental fields and subjected to soil analyses. Experimental soils were sandy loam in texture. Soils had low lime content and salinity, rich in potassium and phosphorus, slightly alkaline and poor in organic matter (Table 2).

Table 2. Physical and chemical characteristics of experimental soils

\begin{tabular}{|c|c|c|c|c|c|c|c|c|c|c|}
\hline \multirow[b]{2}{*}{ Depth } & \multicolumn{4}{|c|}{ Texture } & \multirow[b]{2}{*}{ pH } & \multirow[b]{2}{*}{$\underset{\%}{\text { Org. Mat. }}$} & \multirow[b]{2}{*}{$\mathrm{CaCO}_{3} \%$} & \multirow[b]{2}{*}{$\begin{array}{c}\mathrm{K}_{2} \mathrm{O} \\
\mathrm{kg} \mathrm{ha}^{-1}\end{array}$} & \multirow[b]{2}{*}{$\begin{array}{c}\mathrm{P}_{2} \mathrm{O}_{5} \\
\mathrm{~kg} \mathrm{ha}^{-1}\end{array}$} & \multirow[b]{2}{*}{$\begin{array}{c}\text { EC } \\
\mathrm{dS} / \mathrm{m}\end{array}$} \\
\hline & $\begin{array}{c}\text { Clay } \\
\%\end{array}$ & $\begin{array}{c}\text { Silt } \\
\%\end{array}$ & $\begin{array}{c}\text { Sand } \\
\%\end{array}$ & Class & & & & & & \\
\hline $0-40$ & 13.10 & 4.16 & 82.74 & Sandy-Loamy & 7.61 & 1.05 & 0.28 & 1092.20 & 89.63 & 0.49 \\
\hline
\end{tabular}

Climate parameters for the year 2013 before sowing and grass cover formation, the parameters for the years 2014 and 2015 and long-term averages are provided in Table 2. Temperatures in experimental years (2014 and 2015) were generally higher than the long-term averages.
While the precipitations in 2014 were higher than the long-term averages, the precipitations in 2015 were lower than the long-term averages. Long-term relative humidity values were generally higher than the relative humidity values of the experimental years (Table 3 ). 
Table 3. Precipitation, temperature and relative humidity data for the experimental site

\begin{tabular}{|c|c|c|c|c|c|c|c|c|c|c|c|c|}
\hline \multirow{2}{*}{ Months } & \multicolumn{4}{|c|}{ Temperature $\left({ }^{\circ} \mathrm{C}\right)$} & \multicolumn{4}{|c|}{ Precipitation (mm) } & \multicolumn{4}{|c|}{ Relative Humidity (\%) } \\
\hline & 2013 & 2014 & 2015 & LT* & 2013 & 2014 & 2015 & LT* & 2013 & 2014 & 2015 & LT* \\
\hline Janua & 0.8 & 2.0 & -0.9 & -1.7 & 59.9 & 31.6 & 46.8 & & 78.2 & 72.8 & 78.6 & 76.5 \\
\hline & 1.1 & 4.7 & 2.3 & 0.1 & 35.4 & 17.6 & 72.4 & 34.1 & 71.6 & 3.4 & & 73.6 \\
\hline & 5.5 & 8.1 & 6.0 & 5.1 & 36.6 & 88.9 & 122.3 & & 63.4 & & 9.4 & 67.3 \\
\hline & 2.1 & 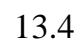 & 8.7 & 10.7 & 43.6 & 2.9 & & & & 7.8 & & 62.3 \\
\hline & & 16 & 15.3 & 15.1 & 31.3 & 39.7 & 57 & & 44.7 & 54.4 & 9.7 & 60.6 \\
\hline & & & & 19 & 12.6 & 52.9 & 98 & & & & & 55.2 \\
\hline & 2.5 & 24.4 & 22.1 & 22.6 & 3.4 & 0.0 & 0.5 & 10.1 & 36.9 & 37.3 & 48.2 & 49.2 \\
\hline & & 24.3 & 23.7 & 22.0 & 0.8 & 47.4 & 9. & & 36.0 & 41.6 & 48.7 & 49.5 \\
\hline & 17.0 & 18.3 & 21.4 & 17.2 & 10.3 & 85.4 & 0.5 & 14.6 & 44.1 & 56.5 & 43.3 & 54.4 \\
\hline & 9.2 & 11.3 & 13.3 & 11.5 & 52.5 & 54.4 & 23.1 & 30.9 & 58.9 & 68.8 & 66.6 & 64.0 \\
\hline & 6.3 & 5.2 & 5.4 & 5.0 & 16.9 & 33.6 & 32.3 & 34.5 & 68.7 & 68.3 & 67.9 & 71.7 \\
\hline December & -3.6 & 4.7 & 3.4 & 0.5 & 25.4 & 39.5 & 38.4 & 39.5 & 72.1 & 75.2 & 73.6 & 76.7 \\
\hline
\end{tabular}

\section{Feed samples and chemical analyses}

Feed samples were initially dried at $70^{\circ} \mathrm{C}$ for 48 hours and ground at mills with $1 \mathrm{~mm}$ sieve. Crude ash contents were determined through ashing the samples at $550{ }^{\circ} \mathrm{C}$ for 8 hours; crude oil contents were determined with ether extraction method by using Soxhlet collector and crude protein contents were determined by multiplying nitrogen content of Kjeldahl method with 6.25 (AOAC, 1990). Neutral detergent fiber (NDF) was determined in accordance with Van Soest and Wine (1967) and acid detergent fiber ADF in accordance with Van Soest (1963) in an ANKOM 200 Fiber Analyzer (ANKOM Technology Corp. Fairport, NY, USA) device.

\section{Determination of total gas and methane productions}

Gas and methane production of tall fescue hays was determined by using in vitro gas production technique developed by Menke at al. (1979). Rumen fluid required for in vitro gas production technique was obtained from three fistula hogget fed with $60 \%$ alfalfa and $40 \%$ barley ration. Clean water and licking stones were provided ad libitum. Rumen fluids were sampled before morning feeding of the animals, samples were filtered through sixlayer cheesecloth and samples were mixed with twice as much artificial saliva (1/2). About $200 \mathrm{mg}$ ground tall fescue hay $(1 \mathrm{~mm})$ was placed in $100 \mathrm{ml}$ glass syringes. Samples were weighed in three replicates. Then, $30 \mathrm{ml}$ buffered rumen fluid was placed into the syringes. As the control groups, three syringes containing only buffered rumen fluid and the syringes containing sample and buffered rumen fluid were placed in water bath at $39{ }^{\circ} \mathrm{C}$ were used. The amount of gas production in control treatment was subtracted from the gas production of syringes with samples to get net gas production. Total gas production $(\mathrm{mL})$ of tall fescue hay after incubation at 39 ${ }^{\circ} \mathrm{C}$ for 24 hours was determined. The gas obtained from tall fescue hay was injected into Infrared Methane Analysis device (Sensor Europe GmbH, Erkrath, Germany) and methane content of the gas was determined (Goel et al., 2008). The following equation was used to calculate the amount of methane production:
Methane production $(\mathrm{mL})=$ Total gas production $(\mathrm{mL})$ $\mathrm{x}$ Methane content (\%)

Metabolic energy (ME), organic matter digestibility (OMD) and net energy lactation (NEL)

ME content of tall fescue hay was calculated with the following equation using 24-hour gas production and chemical composition of the samples (Menke and Steingass, 1988).

$\mathrm{ME}\left(\mathrm{MJ} \mathrm{kg}^{-1} \mathrm{DM}\right)=2.20+0.136 \mathrm{GP}+0.057 \mathrm{CP}+$
$0.002859 \mathrm{CO}^{2}$

OMD $(\%)=14.88+0.889 \mathrm{GP}+0.45 \mathrm{CP}+0.0651 \mathrm{CA}$

$\mathrm{NEL}(\mathrm{MJ} / \mathrm{kg} \mathrm{DM})=0.115 \times \mathrm{GP}+0.0054 \times \mathrm{CP}+$ $0.014 \times \mathrm{CO}-0.0054 \times \mathrm{CA}-0.36$

Where;

DM: Dry matter

GP: 24-hour gas production (mL)

CP: Crude protein content (\%)

CO: Crude oil content (\%)

CA: Crude ash content (\%)

OMD: Organic matter digestibility (\%)

\section{Statistical analysis}

Experimental data were subjected to variance analysis with SAS (SAS Inst. 1999) software in accordance with Randomized Blocks Design. LSD test was used to assess the significance of differences in treatment means.

\section{RESULTS}

\section{Soil salinity and $\mathrm{pH}$}

Salinity of the saturation extracts of the samples taken at the beginning of experiments was $\mathrm{ECe}=0.49 \mathrm{dS} / \mathrm{m}$ and $\mathrm{pH}$ was 7.61. Following the saline irrigation water treatments in the years 2014 and 2015, saturation extract salinity of $T_{0}, T_{1}, T_{2}$ and $T_{3}$ treatments were respectively measured as $1.92 \mathrm{dS} / \mathrm{m}, 3.18 \mathrm{dS} / \mathrm{m}, 4.91 \mathrm{dS} / \mathrm{m}$ and 5.10 
$\mathrm{dS} / \mathrm{m}$ (Table 4). The salts accumulated in the root zones of the plants mostly leached through soil profile because of $132.8 \mathrm{~mm}$ precipitation at the end of August and the beginning of September 2014, thus the soil salinity at harvest dropped below $1.5 \mathrm{dS} / \mathrm{m}$. Compared to initial values, soil salinity levels in $T_{0}, T_{1}, T_{2}$ and $T_{3}$ treatments increased with saline irrigation water treatments respectively by $3.3,6.5,10$ and 10.4 folds at harvest period of 2015. Soil reaction $(\mathrm{pH})$ decreased with increasing soil salinity levels.

Table 4. Effects of saline irrigation water treatments on soil EC and $\mathrm{pH}$ levels

\begin{tabular}{lccccc}
\hline \multirow{2}{*}{ Salt Doses } & \multicolumn{3}{c}{ ECe $(\mathbf{d S} / \mathbf{m})$} & \multicolumn{2}{c}{ pH } \\
\cline { 2 - 5 } & $\mathbf{2 0 1 3}^{*}$ & $\mathbf{2 0 1 5 * *}$ & $\mathbf{2 0 1 3}$ & $\mathbf{2 0 1 5}$ \\
\hline Control & 0.49 & 1.92 & 7.61 & 7.33 \\
3 dS/M & 0.50 & 3.18 & 7.62 & 7.31 \\
5 dS/M & 0.49 & 4.91 & 7.62 & 7.42 \\
8 dS/M & 0.49 & 5.10 & 7.60 & 6.98 \\
\hline
\end{tabular}

*2013 the first year without salinity treatments, the period for grass cover formation

** 2014 the salts accumulated in soil profile were mostly leached through $132.8 \mathrm{~mm}$ precipitation at the end of August and the beginning of September 2014 and the soil salinity at harvest then dropped below 1.5 dS/m. The precipitation in August and September of 2014 was $10.1 \mathrm{~mm}$

\section{Yield and chemical composition}

The results about the effects of different salt doses on yield, morphology and biochemical characteristics of tall fescue and variance analysis results are provided in Table 5. The effects of salt stress on crude ash content was found to be insignificant, the effects on crude protein were found to be significant $(\mathrm{P}<0.05)$ and the effects on the remaining parameters were highly significant $(\mathrm{P}<0.01)$. While the effects of years on crude oil content was found to be significant at $5 \%$ level, the effects of years on the other parameters were found to be significant at $1 \%$ level. The effects of salt $\mathrm{x}$ year interaction on fresh hay yield, dry hay yield, plant height and crude ash content were found to be insignificant, the effects of interaction on crude protein yield, crude protein ratio and crude oil content were found to be significant at 5\% level and the effect on ADF and NDF were found to be significant at $1 \%$ level.
Fresh hay and dry hay yields decreased with increasing salt doses. The lowest yield was obtained from $8 \mathrm{dS} / \mathrm{m}$ treatments respectively with 2577 and $67.6 \mathrm{~kg} \mathrm{ha}^{-1}$ and the highest values were obtained from control treatments respectively with 3638 and $96.7 \mathrm{~kg} \mathrm{ha}^{-1}$. Only $8 \mathrm{dS} / \mathrm{m}$ treatment constituted the lowest group for crude protein yield and there were not any significant differences between the other salt treatments. Plant heights decreased with increasing salt doses and the plant height of 105.37 $\mathrm{cm}$ decreased to $83.59 \mathrm{~cm}$. Crude protein contents $(5.56-$ $6.99 \%)$ increased, but ADF (41.01-39.78\%) and NDF (64.94-62.75\%) ratios decreased with salt doses. While the control group had the greatest NDF ratio, all of the salt treatments constituted the lowest group. Crude oil contents decreased with increasing salt doses and the greatest value was observed in control treatment with $1.61 \%$ and the lowest value was seen in $8 \mathrm{dS} / \mathrm{m}$ salt treatment with $1.42 \%$.

Table 5. Effects of salt stress on fresh hay and dry hay yield, protein yield, plant height and chemical composition of tall fescue plants

\begin{tabular}{lccccccccc}
\hline \multicolumn{1}{c}{ Salt Doses } & HrY & HyY & CPY & PH & CP & ADF & NDF & CA & CO \\
\hline Control & $3638 \mathrm{a}$ & $967 \mathrm{a}$ & $54.45 \mathrm{a}$ & $105.37 \mathrm{a}$ & $5.56 \mathrm{c}$ & $41.01 \mathrm{a}$ & $64.94 \mathrm{a}$ & 12.03 & $1.61 \mathrm{a}$ \\
$3 \mathrm{dS} / \mathrm{M}$ & $3198 \mathrm{~b}$ & $873 \mathrm{~b}$ & $55.10 \mathrm{a}$ & $94.53 \mathrm{~b}$ & $6.17 \mathrm{~b}$ & $40.68 \mathrm{a}$ & $62.75 \mathrm{~b}$ & 11.99 & $1.52 \mathrm{~b}$ \\
$5 \mathrm{dS} / \mathrm{M}$ & $2850 \mathrm{c}$ & $781 \mathrm{c}$ & $52.54 \mathrm{ab}$ & $91.58 \mathrm{c}$ & $6.47 \mathrm{~b}$ & $39.79 \mathrm{~b}$ & $62.87 \mathrm{~b}$ & 11.52 & $1.44 \mathrm{c}$ \\
$8 \mathrm{dS} / \mathrm{M}$ & $2577 \mathrm{~d}$ & $676 \mathrm{~d}$ & $48.42 \mathrm{~b}$ & $83.59 \mathrm{~d}$ & $6.99 \mathrm{a}$ & $39.78 \mathrm{~b}$ & $63.37 \mathrm{~b}$ & 11.21 & $1.42 \mathrm{~d}$ \\
\hline Salt & $* *$ & $* *$ & $*$ & $* *$ & $* *$ & $* *$ & $* *$ & NS & $* *$ \\
Year & $* *$ & $* *$ & $* *$ & $* *$ & $* *$ & $* *$ & $* *$ & $* *$ & $*$ \\
S $\times$ Y & $\mathrm{NS}$ & $\mathrm{NS}$ & $*$ & $\mathrm{NS}$ & $*$ & $* *$ & $* *$ & $\mathrm{NS}$ & $*$ \\
\hline F Value & & & & & & & & & \\
Salt & 91.32 & 46.02 & 4.54 & 91.97 & 28.42 & 6.02 & 8.72 & 1.90 & 365.87 \\
Year & 1141.46 & 154.45 & 512.93 & 772.01 & 374.26 & 289.28 & 16.06 & 19.04 & 6.26 \\
S $\times$ Y & 0.89 & 2.30 & 5.68 & 3.16 & 4.15 & 13.88 & 10.19 & 0.89 & 5.83 \\
\hline
\end{tabular}

HrY: herbage yield (kg/da); HyY: hay yield (kg/da); CPY: crude protein yield ( $\mathrm{kg} / \mathrm{da}) ; \boldsymbol{P H}:$ plant height $(\mathrm{cm}) ; \boldsymbol{C P}:$ crude protein $(\%) ; \boldsymbol{A D F}:$ acid

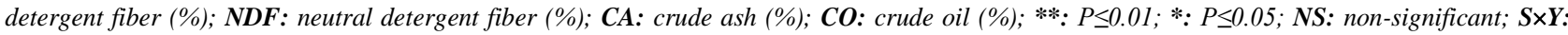
salt year interaction

\section{Gas, methane production, metabolic energy and organic matter digestibility}

The effects of different salt treatments on gas and methane production, ME, NEL and OMD of tall fescue hay and variance analysis results are provided in Table 6 . Salt doses, years and salt $\mathrm{x}$ year interaction had highly significant effects on GP, ME, NEL and OMD $(\mathrm{P}<0.01)$. While the effects of salt stress on methane production 
were found to be highly significant $(\mathrm{P}<0.01)$, effects of salt $\mathrm{x}$ year interaction was found to be significant $(\mathrm{P}<0.05)$ and effects of years were not found to be significant. GP, methane, ME, NEL and OMD increased with increasing salt doses. Gas production increased from $34.17 \mathrm{ml}$ to
$45.00 \mathrm{ml}$; methane production from $4.35 \mathrm{ml}$ to $6.85 \mathrm{ml}$, $\mathrm{ME}$ from 7.00 MJ/kg DM to $8.58 \mathrm{MJ} / \mathrm{kg} \mathrm{DM}$; NEL from $3.75 \mathrm{MJ} / \mathrm{kg} \mathrm{DM}$ to $4.92 \mathrm{MJ} / \mathrm{kg} \mathrm{DM}$ and OMD from $48.54 \%$ to $58.76 \%$.

Table 6. Effects of salt stress treatments on gas and methane production, metabolic energy, net energy lactation and organic matter digestibility of tall fescue plants

\begin{tabular}{|c|c|c|c|c|c|}
\hline Salt Doses & GP & $\mathrm{CH}_{4}$ & ME & NEL & OMD \\
\hline Control & $34.17 \mathrm{~d}$ & $4.35 \mathrm{~d}$ & $7.00 \mathrm{~d}$ & $3.75 \mathrm{~d}$ & $48.54 \mathrm{~d}$ \\
\hline $3 \mathrm{dS} / \mathrm{M}$ & $35.33 \mathrm{c}$ & $4.78 \mathrm{c}$ & $7.19 \mathrm{c}$ & $3.90 \mathrm{c}$ & $49.85 \mathrm{c}$ \\
\hline $5 \mathrm{dS} / \mathrm{M}$ & $42.67 \mathrm{~b}$ & $6.44 \mathrm{~b}$ & $8.22 \mathrm{~b}$ & $4.66 \mathrm{~b}$ & $56.47 \mathrm{~b}$ \\
\hline $8 \mathrm{dS} / \mathrm{M}$ & $45.00 \mathrm{a}$ & $6.85 \mathrm{a}$ & $8.58 \mathrm{a}$ & $4.92 \mathrm{a}$ & $58.76 \mathrm{a}$ \\
\hline Salt & ** & $* *$ & $* *$ & $* *$ & $* *$ \\
\hline Year & $* *$ & NS & $* *$ & $* *$ & $* *$ \\
\hline SxY & $* *$ & $*$ & $* *$ & $* *$ & $* *$ \\
\hline \multicolumn{6}{|l|}{ F Value } \\
\hline Salt & 334.35 & 177.11 & 336.91 & 373.03 & 333.49 \\
\hline Year & 18.24 & 0.16 & 62.35 & 65.58 & 63.21 \\
\hline SxY & 29.92 & 5.23 & 25.63 & 28.08 & 24.38 \\
\hline
\end{tabular}

GP: Gas Production (mL); CH4: methane (mL); ME: Metabolic Energy (MJ/kg DM); NEL: net energy lactation (MJ/kg DM); OMD: Organic Matter Digestibility (\%); **: $P \leq 0.01$; *: $P \leq 0.05$; NS: non-significant; $\boldsymbol{S} \times \mathbf{Y}$ : salt year interaction

\section{DISCUSSION}

The relationship between relative yield and soil salinity (ECe) of tall fescue in accordance with Maas and Hoffman (1977) model is presented in Figure 1. For fresh hay yield, the threshold soil salinity at which yield loss is observed was identified as $1.85 \mathrm{dS} / \mathrm{m}$ for Olympus cultivar and beyond this threshold value, each $1 \mathrm{dS} / \mathrm{m}$ increase in salinity resulted in $8.17 \%$ yield loss. For dry hay yield, the threshold value was identified as $1.97 \mathrm{dS} / \mathrm{m}$ and yield loss for each unit increase in salinity resulted in
8.15\% yield loss. According to Ayers and Westcot (1989), since the threshold value is between $1.3-3.0 \mathrm{dS} / \mathrm{m}$, Olympus cultivar of tall fescue can be classified as moderately tolerant to salinity. Meadow fescue (Festuca elatior L. subsp. pratensis (Huds) Hack) was also reported to be moderately tolerant to salinity (Grieve et al., 2012; Rhoades et al., 1992). The threshold salinity level and yield loss for meadow fescue was reported as $3.9 \mathrm{dS} / \mathrm{m}$ and 5.3\% (Maas and Hoffman, 1977).

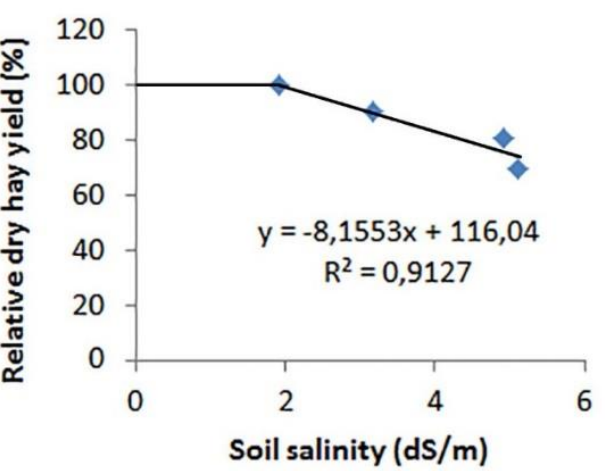

Figure 1. Salinity tolerance model for relative fresh hay and dry hay yield of Festuca arundinacae plants

In present study, fresh hay yields decreased with increasing salt doses. With increasing salt concentration in soil matrix, soil moisture availability and plant water consumption decreases and then ultimately a yield loss is evident (Ayers and Westcot, 1989; Unlukara et al., 2010; Kurunc et al., 2011). Sodium, chlorine and boron in saline waters may have toxic impacts on plants. They may impair plant nutrient uptake and balance (Rhoades et al., 1992). All these impacts may then result in decreases in biomass yields. It was reported in previous studies that salinity retarded plant development and growth in silage maize (Parlak and Parlak, 2006), alfalfa (Medicago sativa) (Bulut, 2011), Persian clover (Trifolium resupinatum L.) (Ates and Tekeli. 2007) retarded root and shoot development in maize (Zea mays) and reduced fresh hay yields (Bilgin et al., 2008). On the other hand, slight salinity levels had positive impacts on dry hay yield of grasspea (Lathyrus sativus L.) (Safi, 2012). Increasing salt doses reduced dry matter yield in birdfoot deervetch (Lotus corniculatus) and Fescuta sp. (Oliveira et al., 2008). 
Plant heights decreased with increasing salt doses. It was reported in a study investigating the effects of water and salt stress on morphological characteristics of grasspea plants, slight salinity levels $(2 \mathrm{dS} / \mathrm{m})$ positively influenced plant heights (Safi, 2012). However, in another study investigating the effects of irrigation water salinity levels on silage maize yield and soil salinity, decreasing plant heights were reported with increasing salinity levels (Parlak and Parlak, 2006). In a study carried out for reclamation of saline-alkaline soils of Harran plain, tall fescue plants were used as the experimental material and the best results for plant heights were obtained from soils with quite low salt and $\mathrm{Na}^{+}$levels. Increasing salinity and $\mathrm{Na}^{+}$levels usually decrease plant heights (Akil, 2008).

Since the digestibility of ADF is quite slow (Van Soest, 1994) and NDF slows down the digestibility of the feeds and thus creates a sense of fullness in animals (Uzun et al., 2013), they are desired to be at low levels in feed rations. Uzun et al. (2013) reported decreasing ADF and NDF ratios in bitter vetch (Vicia ervilia) plants with increasing salt doses. It was also reported that increasing salt doses reduced NDF ratios in forage grasses (BenGhedalia et al., 2001) and different meadow plants (Robinson et al., 2004). In present study, ADF and NDF ratios decreased with increasing salt doses. According to feed quality standards developed by Rohweder et al. (1978), current ADF ratios were classified as either second or third class and NDF ratios were classified as forth class.

Salt stress increased crude protein ratio of tall fescue cv. (Olympus) plants. However, different relationships were reported between salt stress and protein ratios of plants in previous studies. In a study investigating the effects of irrigation water salinity levels on silage sorghum yield and soil salinity, decreasing crude protein ratios were reported with increasing salinity levels (Parlak and Parlak, 2006). Salinity hindered leaf protein in oat (Kumar et al., 2010) and cucumber (Abed Alrahman et al., 2005). However, increasing crude protein ratios were reported with increasing salinity levels in bitter vetch (Uzun et al., 2013), alfalfa and different meadow hays (Suyama et al., 2007). Although there are some previous studies reporting increasing crude ash contents with salt stress (Parlak and Parlak, 2006; Al-Ghumaiz, 2013), effects of salt stress on crude ash contents were not found to be significant in present study.

The in vitro gas quantities are directly related to fermentable carbohydrate quantities in feeds (Blummel and Orskov, 1993). Increasing ADF and NDF ratios may decrease crude protein, crude oil and carbohydrate contents of feeds (Kaplan et al., 2014). In present study, decreasing ADF and NDF ratios with salt stress increased crude protein and carbohydrate contents. Then, increasing carbohydrate contents increased in vitro gas production (Blummel and Orskov, 1993). ME and OMD of tall fescue hay were calculated by using 24-hour in vitro gas production, crude protein, crude oil and crude ash contents of the hays. These values (except for crude oil) all increased with salt stress, thus resulted in increased ME and OMS (Menke and Steingass, 1988). Lopez et al. (2010) classified anti-methanogenic potential of feeds based on methane ratio of in vitro gas as: low (>\%11 and $\leq \% 14)$, medium $(\%>6$ and $<\% 11)$ and high (>\%0 and $<\% 6)$. It was observed in present study that salt stress increased the anti-methanogenic potential of Festuca sp. The anti-methanogenic potential was found to be medium only at $8 \mathrm{dS} / \mathrm{m}$ and low in other treatments.

Current findings revealed that hay and crude protein yields decreased, but ADF and NDF contents increased with increasing salt stress. Crude protein, ME, OMD, NEL, gas and methane production also increased with increasing salt doses. Since a loss in crude protein yield was not observed until $8 \mathrm{dS} / \mathrm{m}$ salinity level and antimethanogenic potential of tall fescue hay was low at this salinity level, it was concluded that tall fescue could reliably be cultivated over the soils with a salinity level of less than $8 \mathrm{dS} / \mathrm{m}$.

\section{ACKNOWLEDGEMENT}

Authors wish to thank Scientific Research Projects Department of Erciyes University for the financial support provided for this study (Grand No: FYL-2013-4790).

\section{LITERATURE CITED}

Abed Alrahman, N. M., R. A. Shibli, K. Ereifej and M. Y. Hindiyeh. 2005. Influence of salinity on growth and physiology of in vitro grown cucumber (Cucumis sativus L.) JJAS. 1 (1):93-105.

Akil, H. 2008. Phytoremediation of calcareous saline-sodic soils of the Harran Plain. Master Thesis, Harran University (in Turkish).

Al-Ghumaiz, N.S. 2013. Response of five introduced forage grass cultivars to salinity stress under irrigation. Grassland Sci Eur. 18: 282-284.

Allakhverdiev, S.I., A. Sakamoto, Y. Nishiyama, M. Inaba and N. Murata. 2000. Ionic and Osmotic Effects of $\mathrm{NaCl}-$ Induced Inactivation of Photosystems I and II in Synechococcus sp. Plant Physiol. 1047-1056.

Alshammary, S.F. 2013. Effect of salinity on -ion relations of four turfgrasses. J Food Agric Environ. 11: 1321-1326.

AOAC, 1990. Official Method of analysis. 15th. ed. Association of Official Analytical Chemist, Washington, DC. USA.

Ates, E. and A. S. Tekeli. 2007. Salinity tolerance of persian clover (Trifolium resupinatum var. majus Bois.) lines at germination and seedling stage. WJAS, 3 (1): 71-79.

Ayers, R.S. and D.W. Westcot. 1989. Water quality for agriculture. FAO Irrigation and Drainage Paper No. 29, Rome.

Banuelos, G.S., A. Zayed, N. Terry, L. Wu, S. Akohoue and S. Zambrzuski. 1996. Accummulation of selenium by different plant species grown under increasing sodium and calcium chloride salinity. Plant Soil. 183:49-59.

Ben-Ghedalia, D., R. Solomon, J. Miron, E. Yosef, Z. Zomberg, E. Zukerman, A. Greenberg and T. Kipnis. 2001. Effects of water salinity on the composition and in vitro digestibility of winter-annual ryegrass grown in teh Arava desert. Anim Feed Sci Tech. 91: 139-147.

Bilgin, O., I. Baser, Z. Korkut, A. Balkan and N. Saglam. 2008. The impacts on seedling root growth of water and salinity stres in maize (Zea mays indentata Sturt.). Bulg J Agric Sci. 14: $313-320$

Bulut, T. 2011. The Effects of Irrigation Water Quality and Leaching Requirements on Germination and Vegetatif 
Growth of Alfalfa. Master Thesis, Ankara University (in Turkish)

Blummel, M. and E.R. Orskov. 1993. Comparison of an in vitro gas production and nylon bag degradability of roughages in predicting feed intake in cattle. Anim Feed Sci Technol. 40: 109-119.

Canbolat, O. 2012. Comparison of in vitro gas production, OMD, relative feed value and metabolizable energy contents of some cereal forages. Kafkas Univ J Vet Med. 18 (4): 571 577.

Efe, B. 2010. Using possibilities of some water holding polymers in lawn areas. Ankara University Graduate School of Natural and Applied Sciences Department of Field Crops., Master Thesis (in Turkish).

Goel, G., H.P.S. Makkar and K. Becker. 2008. Effect of Sesbania sesban and Carduus pycnocephalus leaves and fenugreek (Trigonella foenum-graecum $L$ ) seeds and their extraction partitioning of nutrients from roughage-and concentrate-based feeds to methane. Anim Feed Sci Tech. 147: 72-89.

Grieve, C.M., S.R. Grattan and E.V. Maas. 2012. Plant Salt Tolerance. In: Wallender, W.W., Tanji, K.K. (eds), Agricultural Salinity Assessment and Management. American Society of Civil Engineers 405-459., Reston, Virginia.

Hanslin, H.M. and T. Eggen. 2005. Salinity tolerance during germination of seashore halophytes and salt-tolerant grass cultivars. Seed Sci Res. 15, 43-50.

Kaplan, M., O. Baran, A. Unlukara, H. Kale, M. Arslan, K. Kara, S. Buyukkilic Beyzi, Y. Konca and A. Ulas. 2016. The Effects of Different Nitrogen Doses and Irrigation Levels on Yield, Nutritive Value, Fermentation and Gas Production of Corn Silage. Turk J Field Crops 2: 100-108.

Kaplan, M., A. Kamalak, A.A. Kasra and I. Guven. 2014. Effect of maturity stages on potential nutritive value, methane production and condensed tannin content of Sanguisorba minor Hay. Kafkas Univ. J Vet Med. 20: 445-449.

Kumar, A., S. Agarwal, P. Kumar and A. Singh. 2010. Effects of salinity on leaf grain protein in some genotypes of oat (Avena sativa L.). Res. Sci. Technol. 2: 85-87.

Kurunc, A., A. Unlukara and B. Cemek. 2011. Salinity and drought affect yield response of bell pepper similarly. Section B - Plant and Soil Science, Acta Agr Scand. 61: 514-522.

Lin, B., J.H. Wang, Y. Lu, Q. Liang and J.X. Liu. 2013. In vitro Rumen fermentation and methane production are influenced by active components of essential oils combined with fumarate. Anim Physiol Anim Nutr. 97: 1-9.

Lopez, S., H.P.S. Makkar and C.R. Soliva. 2010. Screening plants and plant products for methane inhibitors. In vitro screening of plant resources for extra nutritional attributes in ruminants: Nuclear and related methodologie. Ed; Vercoe PE, Makkar HPS, Schlink A, London, New York. USA.

Maas, E.V. and G.J. Hoffman. 1977. "Crop salt tolerance: Current assessment." J Irrig Drain E-ASCE Division., 103 $115-134$.

Martin, R.C., K. Glover-Cutter, J.C. Baldwin and J.E. Dombrowski. 2012. Identification and characterization of a salt stressinducible zinc finger protein from Festuca arundinacea. BMC Research Notes., 1756-0500/5/66.

Menke, K.H., L. Raab, A. Salewski, H. Steingass, D. Fritz and W. Schneider. 1979. The estimation of the digestibility and metabolisable energy content of ruminant feeding stuffs from the gas production when they are incubated with rumen liquor in vitro. J Agric Sci Camb. 93: 217-222.
Menke, K.H. and H.Steingass. 1988. Estimation of the energetic feed value obtained from chemical analysis and in vitro gas production using rumen fluid. Anim. Res. Dev. 28: 7-55.

Moore, G. 1998. Soilguide: A handbook for understanding and managing agricultural soils. Agriculture Western Australia Bulletin No. 4343.

Munns, R. 2005. Genes and salt tolerance: bringing them together. New Phytol. 167:645-663.

Oliveira, M.M., M.A. Carmona and M.J. Santos. 2008. Saline effects on for age growth and quality. In: Porqueddu C. (ed.), Tavares de Sousa M.M. (ed.). Sustainable Mediterranean grasslands and their multifunction. Zaragoza: CIHEAM / FAO / ENMP / SPPF., 89 -92

Parlak, M. and A.O. Parlak. 2006. The Effect of Different Irrigation Water Salinities on Silage Sorghum (Sorghum bicolor (L.) Moench) Yield and Soil Salinity. Jas. 12 (1): 813.

Rhoades, J.D., A. Kandiah and A.M. Mashali. 1992. The use of saline waters for crop production. FAO Irrigation and Drainage Paper No.48, Rome, Italy.

Robinson, P. H., S. R. Grattan, G. Getachew, C. M. Grieve, J. A. Poss, D. L. Suarez and S. E. Benes. 2004. Biomass accumulation and potential nutritive value of some forages irrigated with saline-sodic drainage water. Anim Feed Sci Tech. 111: 175-189.

Rohweder, D.A., R.F. Barnes, and N. Jorgensen. 1978. Proposed hay grading standards based on laboratory analyses for evaluating quality. J Anim Sci. 47: 747-759.

Safi, S. 2012. Determining the effects of water and salinity stress on plant growth, development, yield and water consumption in grasspea (Abstract). Jafag, 30, 1-12.

SAS, 1999. SAS User's Guide: Statistic. Statistical Analysis Systems Institute Inc., Cary, NC.

Suyama, H., S.E. Benes, P.H. Robinson, S.R. Grattan, C.M. Grieve, and G. Getachew. 2007. Forage yield and quality under irrigation with saline-sodic drainage water: Greenhouse evaluation. Agr Water Manage. 88: 159-172.

Tilaki, G.A.D., B. Shakarami, M. Tabari and B.Behtari. 2010. Increasing salt tolerance in tall fescue (Festuca arundinacea schreb) by seed priming techniques during germination and early growth. Indian J. Agric. Res. 44 : $177-182$.

Uzun, S., O. Uzun, M. Kaplan and A.I. Ilbas. 2013.Response of Bitter Vetch Lines to Salt Stress, Bulg J Agric Sci. 19: 10611067.

Unlukara, A., A. Kurunç, G.D. Kesmez, E.Yurtseven. and D.L. Suarez. 2010. Effects of Salinity on Eggplant (Solanum Melongena L.) Growth and Evapotranspiration. Irrig Drain 59: 203-214.

Unlukara, A., A. Kurunc, G.D. Kesmez and E.Yurtseven. 2008. Growth and evapotranspiration of okra (Abelmoschus esculentus $L$.) as influenced by salinity of irrigation water. $\mathrm{J}$ Irrig Drain E-ASCE, 134: 160-166.

Van Soest, P. J. and R.H. Wine. 1967. The use of detergents in the analysis of fibrous feeds. IV. Determination of plant cell wall constituents. J Assoc Off Ana Chem. 50:50-55.

Van Soest, P.J. 1963. The use of detergents in the analysis of fibre feeds. II. A rapid method for the determination of fibre and lignin. J Assoc Off Ana Chem. 46:829-835.

Van Soest, P. J. 1994. Nutritional Ecology of the Ruminant (2nd Ed.). Cornell University Press. Ithaca, N.Y.

Yan, L., Z.Yingpeng, S. Ming and G. Bimo. 2008. Research Advance in the Effects of Salt Stress on Plant and the Mechanism of Plant Resistance. (Institute of Soil and Fertilizer, Shandong Academy of Agricultural Sciences, Jinan 250100). Chinese Agricultural Science Bulletin. 